\title{
Review
}

\section{Microplastics in the aquatic environment: implications for post-harvest fish quality}

\author{
B. MADHUSUDANA RAO \\ Visakhapatnam Research Centre of ICAR-Central Institute of Fisheries Technology, Visakhapatnam - 530003 \\ Andhra Pradesh, India \\ e-mail:bm.rao@icar.gov.in; bmrcift@gmail.com
}

\begin{abstract}
Though fish meat is good for health, its consumption is determined by post-harvest quality parameters. The "use and dispose" attitude of the public towards plastics coupled with inadequate waste management has led to extensive accumulation of plastic debris in the aquatic environment. Microplastics (plastic particles of $<5 \mathrm{~mm}$ in their longest dimension) in the aquatic environment and fish gut is an emerging concern that has been reported from different regions of the world. The degradation of plastic polymers to micro- and even to nano sized particles smaller than $100 \mathrm{~nm}$ size is of recent major concern. Micro- and nanoplastics are basically inert but they tend to sorb toxic pollutants and harmful microorganisms. Moreover, chemicals added to plastic to impart functional properties pose threat to human health. Fish, either by passive ingestion or active foraging accumulate microplastics in their guts. However, there is paucity of documented evidence on the adverse effect of microplastics on human health due to consumption of such fish. Protocol for the determination of quantity of microplastics in fish flesh needs to be standardised and quality standard to be fixed for the quantity of microplastics that would be considered as a food hazard. There exists an imminent need to perform risk analysis in order to categorise microplastic as a food hazard in fish meant for human consumption. Until then there is no justification to reduce the consumption of fish and fishery products due to apprehension of presence of microplastics.
\end{abstract}

Keywords: Fish quality, Food hazard, Microbeads, Microplastics, Plastics, Polyethylene

\section{Introduction}

Fish meat is packed with many nutrients that are beneficial for human health, with high quality protein, vitamins (A, B, D), minerals (calcium, phosphorus, iron, copper, selenium, magnesium, zinc) and omega-3 fatty acids (Eicosapentaenoic acid, Docosahexaenoic acid). Consumption of fish is associated with low incidences of heart attacks and strokes as omega-3 fatty acids decrease the risk of arrhythmias, lower triglyceride levels, decrease growth rate of atherosclerotic plaques and lower blood pressure (Flick and Martin, 1992; Stone, 1996; KrisEtherton et al., 2002; Mozaffarian and Rimm, 2006; Brouwer, 2008).

Increased public awareness on the benefits of fish has led to increase in consumption of fish. World per capita fish consumption reached $19.7 \mathrm{~kg}$ in 2013 and is showing an increasing trend. The per capita fish consumption in India $(6.1 \mathrm{~kg}$ per person) was lower than other Asian countries such as Indonesia (31.8 kg per person), China (38 kg per person) and Japan (48.9 kg per person) in 2013 (FAO, 2016). India is the second largest producer of fish with production of 11.41 million $t$ in 2016-17 and fish consumption is being promoted for its nutritional and health benefits.

Safety of food is the chief concern of fish consumers and food regulatory agencies all over the world have laid quality guidelines for accepting fish as food. Even though fish is good for health, its consumption is determined by post-harvest quality parameters such as protein breakdown, fat oxidation, microbial numbers, presence of harmful pathogens and toxic chemicals. Pre-harvest condition of the fish plays a key role in determining post-harvest fish quality as it is well recognised that harmful microorganisms and toxic chemicals present in the aquatic environment tend to accumulate in the live fish and severely jeopardise post-harvest fish quality.

Plastics, owing to their user friendliness, cost effectiveness and versatility, have been the choice of material for either substitution of existing products or development of innovative products in the fields of electrical, electronics, medical, cosmetics, automotive, construction, agriculture and food packaging. The versatility of plastics made their presence ubiquitous in all the countries. Global annual production of plastics 
increased from 1.5 million $\mathrm{t}$ in 1950 to 322 million $\mathrm{t}$ in 2015 (Plastics Europe, 2016; Wright and Kelly, 2017) and the demand for plastics is projected to increase to 600 million $\mathrm{t}$ by 2025 and reach 1000 million $\mathrm{t}$ by 2050 (Lusher et al., 2017b).

\section{Plastic waste}

Nearly $10 \%$ of the plastics produced globally ends up in the aquatic environment (Thompson, 2006; Jambeck et al., 2015). The plastic mass in the oceans in relation to fish biomass is projected to reach a ratio of 1 to 3 by 2025 (Jovanovic, 2017) and in some parts of the oceans the mass of plastics has already surpassed the phytoplankton mass (Moore et al., 2001). Deep Indian Ocean floor is already burdened with 4 billion fibers per $\mathrm{km}^{2}$ (Woodall et al., 2014). The economic burden of plastic litter was estimated to be $\$ 13$ billion (UNEP, 2014 ) and $\$ 489$ million is needed to remove microplastics from $1 \%$ of the North Pacific (NOAA, 2016). India generates about 25,000 t of plastic waste every day. Major rivers and drains carry the plastic waste from hinterlands in to the open seas. The United Nations has identified the Ganga-Brahmaputra Meghna river system as one of the ten rivers worldwide that carries enormous amounts of plastic waste in to the marine environment. India was the global host for the United Nations World Environment Day 2018 that had 'Beat Plastic Pollution' as the focal theme. This outlines the global significance of plastic waste as one of the greatest environmental challenges for mankind.

Plastic waste is largely generated from the single use or disposable plastic items such as plastic bags, plastic cutlery, disposable medical devices and plastic packaging of food, electrical appliances and equipment. Food and beverage packaging is the single largest contributor of plastic waste (Galloway, 2015). The increase in the "use and dispose" attitude of the public towards plastics coupled with inadequate waste management by the civic administration has led to extensive accumulation of plastic debris in the aquatic environment. The effect of plastic debris on aquatic animals is obvious as the macroplastics can physically clog the gut and intestines of aquatic animals leading to their mortality due to choking (Kaladharan et al., 2014). Entanglement of fish and turtles in marine debris cause lacerations, increased drag and may lead to death by drowning or starvation (Nelms et al., 2016). However, presence of microplastics in the aquatic environment and fish gut is an emerging concern that has been reported from different aquatic regions of the world. Even tap water $(83 \%$ of the samples collected worldwide and $94 \%$ in the USA) samples were found to be contaminated with microplastics (www.orbmedia.org.

\section{Composition of microplastics}

Microplastics are defined generally, as plastic particles with less than $5 \mathrm{~mm}$ in their longest dimension (GESAMP, 2015) and more specifically defined as plastic particles with size ranging between 0.1 to $5000 \mu \mathrm{m}$ in their longest dimension (EFSA, 2016; Lusher et al., 2017a). The dimensions of the microplastics are comparable to the size of the food ingested by most aquatic animals.

Plastics are basically polymers and the low density polyethylene (LDPE) as well as high density polyethylene (HDPE) are polymers of ethylene. Polyvinyl chloride (PVC) is a polymer of vinyl chloride, polypropylene (PP) is polymer of propylene, polyethylene terephthalate (PET) is polymer of ethylene terephthalate and polystyrene is polymer of styrene, while nylon is a polyamide. Several additional chemicals (additives) such as colours, UV stabilisers, plasticisers, preservatives, antioxidants, fillers and flame retardants are added to the plastics to provide additional features to the final plastic product. Chemically the additives include bisphenolA, bisphenone, brominated flame retardants, phthalates, triclosan and organotins.

\section{Sources of microplastics in the aquatic environment}

Microplastics enter the aquatic environment through primary and secondary sources. The primary source of microplastics is the microbeads present in facial cleaners, facial scrubs, toilet soaps and tooth paste. Microbeads are small sized $(<1 \mathrm{~mm}$ dia) plastic particles that are added to cosmetics and toiletries to enhance their abrasive and cleaning ability. Facial cleaners contain polyethylene microparticles with sizes ranging between $4.1 \mu \mathrm{m}$ to 1.24 $\mathrm{mm}$ (Fendall and Sewell, 2009). Microbeads were reported in commercial cosmetic products in many countries including India (Sharma and Chatterjee, 2017). Microbeads, being non-biodegradable and tiny plastic particles, escape the filtration and treatment processes for waste water and end up in the open aquatic environment.

The secondary source of microplastics is through degradation of mesoplastics ( 5 to $25 \mathrm{~mm}$ ) and macroplastics $(>25 \mathrm{~mm})$. Plastics are highly resistant to microbial degradation in the aquatic environment. However, they breakdown to smaller fragments through the fragmentation/degradation of large plastic items through weathering by abiotic factors such as ultra violet light, water temperature as well as wave and wind action (Andrady, 2015; Browne, 2015; Auta et al., 2017). Expanded polystyrene floats of fishing docks and aquaculture facilities are damaged by boring isopods and in the process expel large quantities of microplastics into the aquatic environment (Davidson, 2012). Polyester fibres from textiles also form sources of microplastics that enter the aquatic environment through domestic and industrial waste water. 


\section{Plastic use in fisheries and aquaculture}

Almost all aspects of fisheries i.e., fish harvest, fish farming, fish packaging and fish transport involve extensive use of plastics. In the fish harvest sector, plastics are used in fish nets, trawls, lines, lures, traps, pingers, in boat construction, fish holds, buoys, floats and fish aggregating devices. In fish farming, plastics are used in cage fabrication, mesh screens, drain pipes, plastic paddle wheel aerators, pond plastic lining, crates as well as for feed and feed supplement packaging. In fish processing, plastics are mainly used in insulated fish boxes, crates, conveyor belts and product packaging. The choice of material depends on the intended use as some plastic materials (polyethylene, polypropylene, expanded polystyrene) float while some other forms of plastics (polyvinyl chloride, polyamide, poly ethylene terephthalate) sink in seawater.

\section{Microplastics in the aquatic animals and environment}

Ingestion of small plastic particles has been reported in more than 690 marine species belonging to different trophic levels (Gall and Thompson, 2015; Lavers and Bond, 2017). Aquatic animals passively ingest microplastics due to their inability to differentiate microplastics and food. The minute size of microplastic particles, buoyancy of the plastic particles and attractive colour of the plastics make them ideal candidates as food for fish. Among aquatic animals, microplastics were reported in clams (Davidson and Dudas, 2016), mussels (Van Cauwenberghe et al., 2015), shrimps (Devriese et al., 2015), crabs (Stasolla et al., 2015), oysters (Sussarellu et al., 2016), whales (Besseling et al., 2015), marine fish (Lusher et al., 2013; Avio et al., 2015; Mazurais et al., 2015; Romeo et al., 2015; Bellas et al., 2016; Guven et al., 2017; Jovanovic, 2017, Foley et al., 2018; Wieczorek et al., 2018); freshwater fish (Sanchez et al., 2014; Phillips and Bonner, 2015; Peters and Bratton, 2016; Jabeen et al., 2017) and farmed fish (Ibrahim et al., 2017). Microplastics were detected in beaches (Veerasingam et al., 2016; Yu et al., 2018), lakes (Sruthy and Ramasamy, 2017), estuarine rivers (Yonkos et al., 2014) and seas (Lima et al., 2014). Microplastics have also been reported from table salt (Yang et al., 2015) and canned fish (Karami et al., 2018).

In India, plastic ingestion was reported in different marine fish such as sardine, mackerel, anchovy, ribbon fishes, dolphin-fish, tunas and several other fishes caught from almost all states along the south-west and south-east coasts (Sulochanan et al., 2011; Sajikumar et al., 2013; Kripa et al., 2014; Kripa, 2018). Plastic items formed $97 \%$ by weight and $99 \%$ by number of the total marine litter in the stake net fisheries of Vembanad Lake, Kerala (Shylaja et al., 2018) and the average weight of plastic covers in the nets was $985 \mathrm{~g} \mathrm{net}^{-1}$ day $^{-1}$. Kaladhran et al. (2017) analysed beach debris collected from 254 selected beaches and provided a synoptic picture of beach debris in India. The plastic items in the litter comprised of nylon nets/ fishing lines, single use carry bags, sachets of soft drinks, edible oils, detergents, beverages, cases of cosmetics, toothpaste, PET bottles and ice cream containers. They reported that the quantity of plastics in beach litter ranged between $0.08 \mathrm{~g} \mathrm{~m}^{-2}$ (Odisha coast) and $25.47 \mathrm{~g} \mathrm{~m}^{-2}$ (Goa coast). Significantly, the archipelagic coasts of Andamans (47\%) and Lakshadweep (40\%) recorded higher proportion of plastic in the beach litter compared to the national average of $14 \%$. However, the percentage occurrence of microplastics of size $50 \mu \mathrm{m}$ to $5 \mathrm{~mm}$ in marine debris is less than 5\% (Kripa, 2018)

Chemical constituents (monomers and additives) of the microplastics contain endocrine disruptors which lead to change in fish behaviour, gastrointestinal irritation, disruption of lipid metabolism, change in microbiome and can cause reproductive problems. Main polymer types found in microplastics from the Qinghai Lake, China were polyethylene and polypropylene (Xiong et al., 2018). Polythene was the most abundant polymer in Adriatic fish species (Giacomo et al., 2015). Similarly, polyethylene and polypropylene were the dominant polymers in microplastics reported in India from beach litter (Veerasingam et al., 2016) and sediment samples from Vembanad Lake (Sruthy and Ramasamy, 2017). However, microplastics of polyamide and poly vinyl alcohol were detected in cage-cultured Asian seabass (Ibrahim et al., 2017).

\section{Food safety implications to the fish consumers}

Plastics are generally inert and have minimal effect on human health. However, monomers of certain plastic polymers, chemical additives added to plastics, toxic chemicals sorbed to microplastics and harmful pathogens attached to the microplastics have the potential to negatively affect human health.

Monomers and endogenous chemical additives: Certain monomers and endogenous chemical additives present in the plastic polymers have deleterious effects on human health (Table 1). Monomers of plastics such as ethylene and ethylene terephthalate are not recognised as significant human health threat but styrene exhibits estrogen like activity (Yang et al., 2011) and vinyl chloride is a genetoxic and mutagenic agent (Giri, 1995; BrandtRauf et al., 2012). Additives to the plastics viz., phthalates, bisphenol A, nonylphenols and flame retardants act as endocrine disruptors (Diamanti-Kandarakis et al., 2009; Halden, 2010; Bang et al., 2012; Ludovic et al., 2017). 
Table 1. Effect of constituents of microplastics on human health

\begin{tabular}{|c|c|c|}
\hline Plastic component & Polymer/ Function & Effect on human health \\
\hline \multicolumn{3}{|l|}{ Plastic monomer } \\
\hline Ethylene & $\begin{array}{l}\text { High density polyethylene (HDPE) and Low } \\
\text { density polyethylene (LDPE) }\end{array}$ & $\begin{array}{l}\text { Not recognised as a significant human } \\
\text { health threat. }\end{array}$ \\
\hline Ethylene terephthalate & Polyethylene terephthalate (PET) & No significant human health threat. \\
\hline Styrene & Expanded polystyrene (EPS) & $\begin{array}{l}\text { Bind to estrogen receptors and exhibit } \\
\text { estrogen like activity. }\end{array}$ \\
\hline Vinyl chloride & Polyvinyl chloride (PVC) & Genotoxic and mutagenic toxicant. \\
\hline \multicolumn{3}{|l|}{ Plastic additive } \\
\hline $\begin{array}{l}\text { Phthalates } \\
\text { Di-(2-ethylhexyl) phthalate, Dibutyl } \\
\text { phthalate and } \\
\text { Diethyl phthalate. }\end{array}$ & $\begin{array}{l}\text { Increase flexibility of the plastic and makes it } \\
\text { resistant to breakage }\end{array}$ & Endocrine disruptor \\
\hline Bisphenol A & $\begin{array}{l}\text { Functions as plasticiser and used as the } \\
\text { monomeric building block of plastics. }\end{array}$ & $\begin{array}{l}\text { Endocrine disrupting compound and } \\
\text { it binds to the estrogen receptors. }\end{array}$ \\
\hline $\begin{array}{l}\text { Flame retardants: } \\
\text { Polybrominateddiphenyl ethers and } \\
\text { hexabromocyclododecane }\end{array}$ & Reduces plastic flammability & $\begin{array}{l}\text { Endocrine disruptor, teratogenicity } \\
\text { and liver and kidney toxicity }\end{array}$ \\
\hline Nonylphenols & $\begin{array}{l}\text { Stabiliser in food packaging and Antioxidant } \\
\text { in polymers }\end{array}$ & Endocrine disruptor \\
\hline
\end{tabular}

Sorption of chemicals to microplastics: The relatively higher surface area to volume ratio of microplastics provides greater potential for sorption of harmful chemicals and subsequent leaching of these toxic compounds. Persistent toxic substances such as dicholrodiphenyltrichloro ethane (DDT), polycyclic aromatic hydrocarbons (PAH) and polychlorinated biphenyl (PCB) accumulate on microplastics. Heavy metals on the microplastics are either present during plastic manufacture (as stabilizers, antioxidants, dyes or antifouling) or may be sorbed from the aquatic environment. Ashton et al. (2010) showed that virgin polyethylene absorbed aluminum, copper, iron, lead, manganese, silver and zinc from seawater. Zhang et al. (2015) reported $2.4 \mathrm{mg} \mathrm{g}^{-1}$ PAHs and $0.1 \mathrm{mg} \mathrm{g}^{-1}$ in plastic pellets recovered from beaches in China. Moreover, the rate of release of chemicals (desorption) from the microplastics is 30 times faster in simulated digestive environment compared to seawater (Bakir et al., 2014).

Pathogenic bacteria on microplastics: Microplastics are potential surfaces for bacterial biofilm formation. Microorganisms can establish themselves as biofilm on floating plastics within a short period of 7 days. Ogonowski et al. (2018) observed that microplasticsassociated biofilm forming microbial communities were distinctly different from those on the non-plastic substrates. Plastics hosted greater than two-fold higher abundance of Burkholderiales whereas the non-plastic substrates had a significantly higher proportion of Actinobacteria and Cytophagia. It is possible that biofilm microbiome may harbour human pathogens and spoilage bacteria. Pathogenic Vibrio species namely $V$. alginolyticus, $V$. coralliilyticus, $V$. fluvialis, $V$. harveyi, V. parahaemolyticus and $V$. splendidus were detected on microplastics (Kirstein et al., 2016). Moreover, biofilms act as rafts and aid in the transport of microorganisms to distant places in the aquatic environment.

Pathways of transfer of microplastics from aquatic environment to humans through aquatic animals

Human health risks are mainly attributed to the chemical additives on plastics and sorbed toxic compounds present on microplastics. The pathway for ingestion of microplastics present in the aquatic environment by humans is depicted in Fig. 1. In fish, after ingestion, the microplastics may translocate across the gastrointestinal tract and gills and enter the circulatory system. The translocation may happen either through trancellular uptake or by paracellular diffusion (Wright and Kelly, 2017). Through blood circulation, microplastics reach different organs and muscles. Humans consuming this microplastics laden fish meat are vulnerable to the effects of microplastics. Microplastics physically attach to the skin and gills of the fish and the consumption of fish skin and gill tissue provides another route of transmission of microplastics to the humans. Karami et al. (2017) noticed 


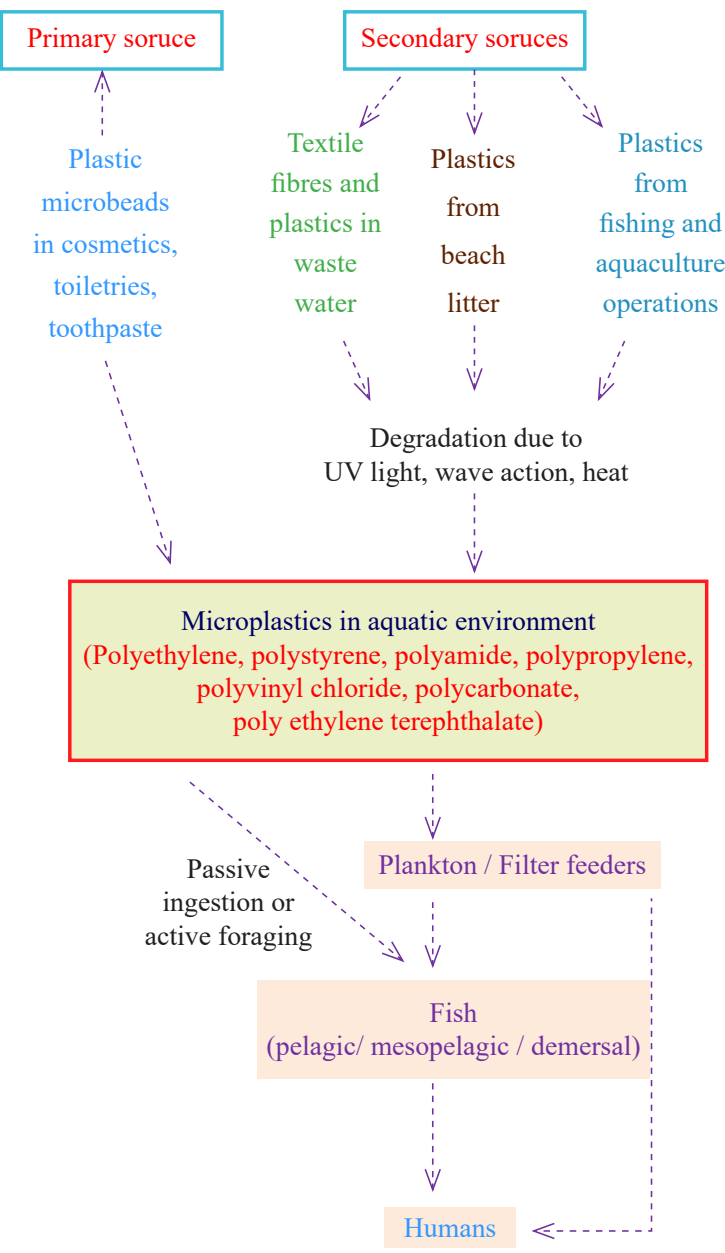

Fig. 1. Pathway for ingestion of microplastics present in aquatic environment by humans

that eviscerated flesh of dried fish contained higher microplastic particles than the viscera and gills indicating post-harvest safety concerns to the consumer. Filter feeders filter larger volumes of water for food and in the process end up retaining microplastics in their body. Moreover, depuration for 3 days does not clear the microplastics from the filter feeders. It was estimated that Chinese shellfish consumers could be exposed to 100,000 particles of microplastics per annum (Wright and Kelly, 2017) and European shellfish consumer might consume 11,000 microplastic particles per annum (Van Cauwenberghe and Janssen, 2014).

\section{Detection of microplastics in fish meat}

The polymer identity in the gut and intestinal contents of fish is usually established employing Raman spectroscopy or Fourier Transform Infrared Spectroscopy (FTIR) (Miller et al., 2017). However, protocol for the determination of quantity of microplastics in fish flesh has not been standardised and quality standard has to be fixed for the quantity of microplastics that would be considered as a food hazard. The existing quality criterion laid for water and fish meant for human consumption (e.g., EU, 1998; FSSAI, 2011) would meet the requirements of determining fish quality vis-à-vis the contaminants such as toxic chemicals and pathogenic bacteria adsorbed/ absorbed to microplastics.

\section{Effect of microplastics on human health}

Microplastics, either ingested or inhaled induce localised particle toxicity by inducing an immune response. In the human body, after ingestion of microplastic laden food, the microplastics first interacts with the mucus layer of the gastrointestinal tract. The microplastic particles aggregate and cross the mucosal layer and come in contact with the epithelial cells. The microplastics then translocates to lymphatic and circulatory system and via these systems reach and accumulate in organs such as liver, kidneys, spleen, heart and brain thereby impact human wellbeing (Volkheimer, 1975; Sass et al., 1990; Hodges et al., 1995; Rieuxet al., 2005; Geiser et al., 2014; Wright and Kelly, 2017). The Peyer's patches of the small intestine are considered the major sites of translocation of microplastic particles (Powell et al., 2010). Hydrophilic and positively charged microplastic particles circulate for longer periods of time (Silvestre et al., 2011). The microplastics are eliminated through urine and faeces (Galloway, 2015).

Impact of consumption of microplastic laden fish on human health

Finfish are generally consumed in degutted form processed as fish steaks, fish fillet, canned fish or as battered and breaded products. The accumulation of microplastics is generally in the fish gut and removal of the gastrointestinal tract negates potential adverse health effects to the fish consumers. However, safety concerns exist for consumers of filter feeders such as clams and mussels when they are consumed in ungutted form; but this practice is uncommon in India.

The most commonly used plastic is polyethylene (LDPE, HDPE) but the release of monomers from polyethylene is currently not recognised to represent a significant human health threat (Halden, 2010). Although, the endogenous chemical additives, sorbed toxic chemicals and biofilm pathogens have the potential to cause human health problems, Lusher et al. (2017b) opined that the contamination burden of harmful chemical contaminants and additives in microplastics would be less than $0.1 \%$ of the total dietary exposure of humans to these compounds even after assuming that the highest concentration of the toxic contaminants are completely released in the human gastrointestinal tract. The potential of microplastics to 
negatively affect human health is understudied (Galloway, 2015) and with the limited research data it may not be appropriate to categorise microplastics containing fish as a food hazard. Hence, there is a need to elucidate the long term impact of microplastics on human health so as to categorise it as a food hazard associated with fish. Until then there is no justification to reduce the consumption of fish and fishery products due to fear of microplastics. However, research on microplastic contamination in fish and its effect on human health need to be actively pursued. Simultaneously, plastic waste disposal in to the aquatic environment needs to be curbed.

\section{Nanoplastics}

Nanoplastics are plastic particles that have a size (diameter/length) of less than $100 \mathrm{~nm}(0.1 \mu \mathrm{m})$. They are either formed as products of progressive degradation from macro- and microplastics or are released directly into the environment. Nanoplastics generally enter the food web through algae, bacteria or filter feeding aquatic organisms (Koelmans et al., 2015; Mattson et al., 2015). They are perceived to be more harmful than the microplastics as their nano-size enables them to move across cell membranes and adversely impact cell functioning (Galloway, 2015; Vethaak and Leslie, 2016). Moreover, the smaller size of nanoplastics has the scope to concentrate toxic compounds either inherent in their production process or sorbed from the aquatic environment. Methods such as electron microscopy, field flow fractionation, multiple wavelength UV-VIS spectrometry, or dynamic light scattering have been used in laboratories to detect nanoplastics. However, presently there are no established analytical methods to detect nanoplastics in the aquatic environment (Mattsson et al., 2015; Carbery et al., 2018). Compared to microplastics, very little is known about nanoplastics. Microplastics exist as spheres, beads, fibers or fragments in the environment but the shape of nanoparticles in the aquatic environment is relatively unknown. The chemistry of the nanoplastics formed from progressive degradation of larger plastic fragments and their chemical behaviour in not known (Mendoza et al., 2018). The paucity of information regarding nanoplastics needs to be addressed before any assessment can be made about the risk potential of nanoplastics (SAPEA, 2019).

Strategies to mitigate microplastics in the aquatic environment and areas for further research

- The plastic release to the aquatic environment needs to be drastically reduced. Primary source of microplastics i.e., microbeads are classified as unsafe for use in cosmetic products by the Bureau of Indian Standards. There is an urgent need to prohibit the use of microbeads in cosmetics towards reducing microplastics pollution. Toiletries and cosmetics products containing microplastics were recently prohibited in the US, Canada and the UK.

- Better waste management practices by creating recycling infrastructure are needed to eliminate the key sources of plastic pollution before they reach the aquatic environment

- Enhance public education through nationwide campaigns such as 'Beat Plastic Pollution' campaign of the United Nations and 'Green Good Deed' of Ministry of Environment, Forests and Climate Change, Government of India and campaigns to emphasise refuse, reuse and recycle plastics.

- Strengthen and encourage product innovation for biodegradable alternatives to plastic polymers e.g. use of natural alternatives to additives used in plastic manufacture, edible cutlery, paper straws, biodegradable food wrappings and edible food coatings

- The microplastics sorb harmful chemicals from the aquatic environment and so measures to mitigate the entry of toxic pollutants into the aquatic environment would minimise the adverse impact of microplastics on fish consumers.

- Research on the sorption dynamics i.e. adsorption/ absorption of chemicals and bacteria to different types of microplastics (PE, PP, PS, PVS, PET) and their rate of release in different aquatic environments (freshwater, brackishwater and seawater) is necessary.

- Impact of processing (blanching, cooking, retorting, canning, pickling, freezing, freeze drying, fermentation, smoking, drying) on microplastic is another area of research to be undertaken.

- Standardisation of protocol for estimation of microplastics from fish tissue is necessary for assessing post-harvest quality of fish.

- Develop methods to detect and quantify nanoplastics in the aquatic environment.

There is paucity of data on the occurrence of microplastics in water, sediment and animals in the aquatic environments in India and there is imminent need for generating data as evidence for framing food quality regulations. Knowledge gaps exist regarding the impact of micro- and nanoplastics on the health of the aquatic animals and the safety of the fish consumers. Close interdisciplinary research collaboration between marine/aqua biologists, food scientists and health care professionals is the way forward for successfully addressing the challenges posed by micro- and nanoplastics in the aquatic environment.

\section{Conclusion}

In the marine environment, it takes nearly 320 years to disintegrate $1 \mathrm{~mm}$ sized microplastic to nano-sized plastic particle (Koelmans et al., 2015). This indicates that the 
amount of microplastics already present in the environment will be impacting aquatic animal health and human health for years to come. However, the potential of microplastics to negatively affect human health is understudied but it has to be emphasised that transfer of microplastics through fish to humans is one of the major challenges for food safety. Concerted global action plan (GAP) to mitigate microplastics in the aquatic environment is an immediate priority but based on the quantum of plastic already present in the aquatic environment, visualising microplastic free aquatic environment appears to be a distant dream; but today's dreams may be tomorrow's reality.

\section{References}

Andrady, A. L. 2015. Persistence of plastic litter in the oceans. In: M. Bergmann, L. Gutow, M.Klages (Eds.), Marine anthropogenic litter. Springer, Berlin, p. 57-72.

Ashton, K., Holmes, L. and Turner, A. 2010. Association of metals with plastic production pellets in the marine environment. Mar. Pollut. Bull., 60: 2050-2055. doi: 10.10 16/j.marpolbul.2010.07.014.

Auta, H.S., Emenike, C. and Fauziah, S. H. 2017. Distribution and importance of microplastics in the marine environment: a review of the sources, fate, effects and potential solutions. Environ. Int., 102: 165-76. doi: 10.1016/j.envint.20 17.02. 013 .

Avio, C. G., Gorbi, S. and Regoli, F. 2015. Experimental development of a new protocol for extraction and characterisation of microplastics in fish tissues: First observations in commercial species from Adriatic Sea. Mar. Environ. Res., 111: 18-26. doi: 10.1016/j.marenvres. 2015.06.014.

Bakir, A., Rowland, S. J. and Thompson, R. C. 2014. Enhanced desorption of persistent organic pollutants from microplastics under simulated physiological conditions. Environ. Pollut., 185: 16-23.

Bang, D. Y., Kyung, M., Kim, M. J., Jung, B.Y., Cho, M. C., Choi, S. M., Kim, Y. W., Lim, S. K., Lim, D. S., Won, A. J., Kwack, S. J., Lee, Y., Kim, H. S. and Lee, B. M. 2012. Human risk assessment of endocrine-disrupting chemicals derived from plastic food containers. Compr. Rev. Food Sci. F., 11: 453-470.

Besseling, E., Foekema, E. M., van Franeker, J. A., Leopold, M. F., Kuhn, S., Rebolledo, E. L. B., Hebe, E., Mielke, L., Ijzer, J., Kamminga, P. and Koelmans, A. A. 2015. Microplastic in a macro filter feeder: Humpback whale Megaptera novaeangliae. Mar. Pollut. Bull., 95: 248-252. doi: 10.1016/j.marpolbul.2015.04.007.

Bellas, J., Martinez-Armental, J., Martinez-Camara, A., Besada, V. and Martinez-Gomez, C. 2016. Ingestion of microplastics by demersal fish from the Spanish Atlantic and Mediterranean coasts. Mar. Pollut. Bull., 109: 55-60. doi: 10.1016/j.marpolbul.2016.06.026.
Brandt-Rauf, P. W., Li, Y., Long, C., Monaco, R., Kovvali, G. and Marion, M. J. 2012. Plastics and carcinogenesis: The example of vinyl chloride. J. Carcinog., 11: 5 pp.

Brouwer, I. A. 2008. Fish, omega-3 fatty acids and heart disease. In: Borresen, T. (Ed.), Improving seafood products for the consumer. CRC Press, Woodhead Publishing Ltd., England, 165 pp.

Browne, M. A. 2015. Sources and pathways of microplastic to habitats. In: Bergmann, M., Gutow, L. and Klages, M. (Eds.), Marine anthropogenic litter. Springer, p. 229-244.

Carbery, M., O'Connor, W. and Thavamani, P. 2018. Trophic transfer of microplastics and mixed contaminants in the marine food web and implications for human health. Environ. Int., 115: 400-409. https://doi.org/10.1016/j. envint.2018.03.007.

Davidson, T. M. 2012. Boring crustaceans damage polystyrene floats under docks polluting marine waters with microplastic. Mar. Pollut. Bull., 64: 1821-1828.

Davidson, K. and Dudas, S. E. 2016.Microplastic ingestion by wild and cultured Manila clams (Venerupis philippinarum) from Baynes Sound, British Columbia. Arch. Environ. Contam. Toxicol., 71: 147-156.doi: 10.1007/s00244-0160286-4.

Devriese, L. I., van Der Meulen, M. D., Maes, T., Bekaert, K., Paul-Pont, I., Frere, L., Robbens, J. and Vethaak, D. 2015. Microplastic contamination in brown shrimp (Crangon crangon, Linnaeus 1758) from coastal waters of the Southern North Sea and Channel area. Mar. Pollut. Bull., 98: 179-187.doi: 10.1016/j.marpolbul.2015.06.051.

Diamanti-Kandarakis, E., Bourguignon, J. P., Giudice, L. C., Hauser, R., Prins, G. S., Soto, A. M., Zoeller, R. T. and Gore, A. C. 2009. Endocrine-disrupting chemicals: An Endocrine Society scientific statement. Endocr. Rev., 30: 293-342.

EFSA 2016. Presence of microplastics and nanoplastics in food, with particular focus on seafood. EFSA J., 14: 4501. doi.org/10.2903/j.efsa.2016.4501.

EU 1998. Council directive 98/83/EC of 3 November 1998 on the quality of water intended for human consumption. Official J. Eur. Communities, 330: 32-54.

FAO 2016. Fishery and aquaculture statistics.Food Balance Sheets 1961-2013 (Fishstat J). FAO Fisheries and Aquaculture Department [online or CD-ROM], Updated 2016. Food and Agriculture Organisation, Rome. http:// www.fao.org/fishery/statistics/software/fishstatj/en.

Foley, C. J., Feiner, Z. S., Malinich, T. D. and Hook, T. O. 2018 A meta-analysis of the effects of exposure to microplastics on fish and aquatic invertebrates. Sci. Total Environ., 631-632: 550-559. doi: 10.1016/j.scitotenv.2018.03.046.

Fendall, L. S. and Sewell, M. A. 2009. Contributing to marine pollution by washing your face: Microplastics in facial cleansers. Mar. Pollut. Bull., 58: 1225-1228. doi.org/10. 1016/j.marpolbul.2009.04.025. 
Flick, J. R. and Martin, R. K. 1992.The implications of omega 3 fatty acids in human health. In: Advances in seafood biochemistry composition and quality. Technomic Publishing Co, Inc., Basel, Switzerland, p. 69-91.

FSSAI 2011. Food Safety and Standards (contaminants, toxins and residues) regulations, 2011, Food Safety and Standards Authority of India, Ministry of Health and Family Welfare, New Delhi, $1^{\text {st }}$ August, 2011; $3^{\text {rd }}$ amendment regulation, 2017 dated, $13^{\text {th }}$ February, 2017.

Gall, S. C. and Thompson, R. C. 2015. The impact of debris on marine life. Mar. Pollut. Bull., 92: 170-179. http://dx.doi. org/10.1016/j.marpolbul.2014.12.041.

Galloway, T. S. 2015. Micro-and nano-plastics and human health. In: Bergmann, M., Gutow, L. and Klages, M. (Eds.), Marine anthropogenic litter, Springer,

Geiser, M., Stoeger, T., Casaulta, M., Chen, S., Semmler-Behnke, M., Bolle, I., Takenaka, S., Kreyling, W. G. and Schulz, H. 2014. Biokinetics of nanoparticles and susceptibility to particulate exposure in a murine model of cystic fibrosis. Part. Fibre Toxicol., 11:19.doi: 10.1186/1743-8977-11-19.

GESAMP 2015. Joint Group of Experts on the Scientific Aspects of Marine Environmental Protection. Sources, fate and effects of microplastics in the marine environment: a global assessment. In: Kershaw, P. J. (Ed.), IMO/FAO/ UNESCO-IOC/UNIDO/WMO/IAEA/UN/UNEP/UNDP Joint Group of Experts on the Scientific Aspects of Marine Environmental Protection, Rep. Stud. GESAMP No. 90: $96 \mathrm{pp}$.

Giacomo, C., Stefania, A. and Regoli, G. F. 2015. Experimental development of a new protocol for extraction and characterization of microplastics in fish tissues: First observations in commercial species from Adriatic Sea. Mar. Environ. Res., 111: 18-26

Giri, A. K. 1995. Genetic toxicology of vinyl chloride-a review. Mutat. Res., 339:1-14.

Guven, O., Gokdag, K., Jovanovi, B. and Kideys, A. E. 2017. Microplastic litter composition of the Turkish territorial waters of the Mediterranean Sea and its occurrence in the gastrointestinal tract of fish. Environ. Pollut., 223: 286294. doi: 10.1016/j.envpol.2017.01.025.

Halden, R.U. 2010. Plastics and health risks. Annu. Rev. Public Health, 31:179-194. doi: 10.1146/annurev.publhealth.0128 09.103714.

Hodges, G. M., Carr, E. A., Hazzard, R. A. and Carr, K. E. 1995. Uptake and translocation of microparticles in small intestine. Morphology and quantification of particle distribution. Dig. Dis. Sci., 40: 967-975.

Ibrahim, Y. S., Rathnam, R., Anuar, S. T., Afiq, W. M. and Khalik, W. M. 2017, Isolation and characterisation of microplastic abundance in Lates calcarifer from Setiu Wetlands, Malaysia. Malaysian J. Anal. Sci., 21: 1054-1064.

Jabeen, K., Su, L., Li, J., Yang, D., Tong, C., Mu, J. and Shi, H. 2017. Microplastics and mesoplastics in fish from coastal and fresh waters of China. Environ. Pollut., 221: 141-149. doi: 10.1016/j.envpol.2016.11.055.

Jambeck, J. R., Geyer, R., Wilcox, C., Siegler, T. R., Perryman, M., Andrady, A., Narayan, R. and Law, K. L. 2015. Plastic waste inputs from land into the ocean. Science, 347: 768-771. DOI: $10.1126 /$ science.1260352.

Jovanovic, B. 2017. Ingestion of microplastics by fish and its potential consequences from a physical perspective. Integr. Environ. Ass. Manag., 13: 510-515. doi: 10.1002/ ieam. 1913.

Kaladharan, P., Asokan, P. K., Koya, K. M. and Bhint, H. M. 2014. Plastic debris in the stomach of a Longman's beaked whale, Indopacetus pacificus (Longman, 1926) stranded off Sutrapada, Veraval, Saurashtra coast, India. J. Mar. Biol. Assoc. India, 56: 92-94. DOI: 10.6024/ jmbai.2014.56.2.01802-15.

Kaladharan, P., Vijayakumaran, K., Singh, V. V., Prema, D., Asha, P. S., Sulochanan Bindu, Hemasankari, P., Loveson Edward, L., Padua Shelton, Veena, S., Anasukoya, A. and Bhint, H. M. 2017. Prevalence of marine litter along the Indian beaches : A preliminary account on its status and composition. J. Mar. Biol. Ass. India, 59: 19-24. doi: 10.6024/jmbai.2017.59.1.1953-03.

Karami, A., Golieskardi, A., Ho, Y. B., Larat, V. and Salamatinia, B. 2017. Microplastics in eviscerated flesh and excised organs of dried fish. Sci. Rep., 7: 5473. doi: 10.1038/s415 98-017-05828-6.

Karami, A., Golieskardi, A., Choo, C. K., Larat, V., Karbalaei, S. and Salamatinia, B. 2018. Microplastic and mesoplastic contamination in canned sardines and sprats. Sci. Total Environ., 612: 1380-1386. doi: 10.1016/j.scitotenv.2017. 09.005 .

Kirstein, I. V., Kirmizi, S., Wichels, A., Garin-Fernandez, A., Erler, R., Loder, M. and Gerdts, G. 2016. Dangerous hitchhikers? Evidence for potentially pathogenic Vibrio spp. on microplastic particles. Mar. Environ. Res., 120: 1-8. doi: 10.1016/j.marenvres.2016.07.004.

Koelmans, A. A., Besseling, E. and Shim, W. J. 2015. Nanoplastics in the aquatic environment.Critical review. In: Bergmann, M., Gutow, L. and Klages, M. (Eds.), Marine anthropogenic litter. Springer International Publishing, p. 326-342.

Koelmans, A. A., Besseling, E., Shim, W. J. 2015. Nanoplastics in the aquatic environment. Critical review. In: Bergmann, M., Gutow, L., Klages, M. (Eds.), Marine anthropogenic litter. Springer International Publishing, Cham, p. 325-340. http://dx.doi.org/10.1007/978-3-319-165103_12.

Kripa,V., Preetha G. N., Dhanya, A. M., Pravitha,V. P., Abhilash, K. S., Mohammed, A. A., Vijayan, D., Vishnu, P. G., Gishnu, M., Anil Kumar, P. S., Khambadker, L. R. and Prema, D. 2014. Microplastics in the gut of anchovies caught from the mud bank area of Alappuzha, Kerala. Mar. Fish. Infor. Serv. T \& E Ser., 219: 27-28. 
Kripa, V. 2018. Marine debris - a threat to sustainable fisheries. In: Prema, D., Molly Varghese, Shelton Padua, Jeyabaskaran, R., Sumithra, T. G., Reshma, K. J., Rekha J. Nair, Sobhana, K. S., Vidya, R., Jeena, N. S., Vivekananda Bharathi, Lavanya Ratheesh, Uma, E. K. and Shylaja, G. (Eds.). Book of Abstracts and Success stories, National Conference on Marine Debris (COMAD 2018), Marine Biological Association of India, 11-12 April 2018, Kochi, p. 19-21.

Kris-Etherton, P. M., Harris, W. S. and Appel, L. J. 2002. Fish consumption, fish oil, omega-3 fatty acids and cardiovascular disease. Circulation, 106: 2747-2757.

Lavers, J. L. and Bond, A. L. 2017. Exceptional and rapid accumulation of anthropogenic debris on one of the world's most remote and pristine islands. Proc. Natl. Acad. Sci., 114: 6052-6055. http://dx.doi.org/10.1073/ pnas. 1619818114.

Lima, A. R. A., Costa, M. F. and Barletta, M. 2014. Distribution patterns of microplastics within the plankton of a tropical estuary. Environ. Res., 132: 146-155. doi: 10.1016/j. envres.2014.03.031.

Ludovic, H., Alexandre, D., Ika, P. P., Camille, L., Ronan, J., Philippe, S. and Guillaume, D. 2017. Occurrence and effects of plastic additives on marine environments and organisms: A review. Chemosphere, 182: 781-793.

Lusher, A. L., McHugh, M. and Thompson, R. C. 2013. Occurrence of microplastics in gastrointestinal tract of pelagic and demersal fish from the English Channel. Mar. Pollut. Bull., 67: 94-99. doi: 10.1016/j. marpolbul.2012.11.028.

Lusher, A. L., Welden, N., Sobral, P. and Cole, M. 2017a. Sampling, isolating and identifying microplastics ingested by fish and invertebrates. Anal. Methods, 9: 1346-1360. doi $=$ "10.1039/C6AY02415G.

Lusher, A. L., Hollman, P. C. H. and Mendoza-Hill, J. J. 2017b. Microplastics in fisheries and aquaculture: status of knowledge on their occurrence and implications for aquatic organisms and food safety. FAO Fisheries and Aquaculture Technical Paper No. 615. Food and Agriculture Organisation, Rome, Italy.

Mattsson, K., Hansson, L. A. and Cedervall, T. 2015. Nanoplastics in the aquatic environment. Environ. Sci. Process. Impact., 17: 1712-1721. http://dx.doi.org/10.1039/C5EM 00227C.

Mazurais, D., Ernande, B., Quazuguel, P., Severe, A., Huelvan, C., Madec, L., Mouchel, O., Soudant, P., Robbens, J., Huvet, A. and Jose-Luis, Z. 2015. Evaluation of the impact of polyethylene microbeads ingestion in European seabass (Dicentrarchus labrax) larvae. Mar. Environ. Res., 112: 78-85. doi: 10.1016/j.marenvres.2015.09.009.

Mendoza, L. M. R., Hrissi Karapanagioti, H. and Alvarez, N. R. 2018. Micro (nanoplastics) in the marine environment: Current knowledge and gaps. Curr. Opin. Environ. Sci. Health, 1: 47-51.
Miller, M. E., Kroon, F. J. and Motti, C. A. 2017. Recovering microplastics from marine samples: A review of current practices. Mar. Pollut. Bull., 123: 6-18. doi: 10.1016/j. marpolbul.2017.08.058.

Moore, C. J., Moore, S. L., Leecaster, M. K. and Weisberg, S. B. 2001. A comparison of plastic and plankton in the North Pacific Central Gyre. Mar. Pollut. Bull., 42: 1297-1300.

Mozaffarian, D. and Rimm, E. B. 2006. Fish intake, contaminants and human health: evaluating the risk and the benefits. JAMA, 296: 1885-1899.

NOAA 2016. How much would it cost to clean up the Pacific Garbage Patches? National Oceanic and Atmospheric Administration, https://response.restoration.noaa.gov/about/ media/how-much-would-it-cost-clean-pacific-garbagepatches.html.

Nelms, S. E., Duncan, E. M., Broderick, A. C., Tamara, S. Galloway, T. S., Godfrey, M. H., Hamann, M., Lindeque, P. K. and Godley, B. J. 2016. Plastic and marine turtles: a review and call for research. ICES J. Mar. Sci., 73: 165-181.DOI: 10.1093/icesjms/fsv165.

Ogonowski, M., Motiei, A., Ininbergs, K., Hell, E., Gerdes, Z., Udekwu, K. I., Bacsik, Z. and Gorokhova, E. 2018. Evidence for selective bacterial community structuring on microplastics. Environ. Microbiol., 20: 2796-2808.

Peters, C. A. and Bratton, S. P. 2016. Urbanisation is a major influence on microplastic ingestion by sunfish in the Brazos River Basin, Central Texas, USA. Environ. Pollut., 210: 380-387. doi: 10.1016/j.envpol.2016.01.018.

Phillips, M. B. and Bonner, T. H. 2015. Occurrence and amount of microplastic ingested by fishes in watersheds of the Gulf of Mexico. Mar. Pollut. Bull., 100: 264-269.doi: 10.1016/j. marpolbul.2015.08.041.

Plastics Europe 2016. Plastics-the Facts 2016: An analysis of European plastics production, demand and waste data. Plastic Europe (www.plasticseurope.org).

Powell, J. J.; Faria, N., Thomas-McKay, E. and Pele, L. C. 2010. Origin and fate of dietary nanoparticles and microparticles in the gastrointestinal tract. J. Autoimmun. 34: J226-233. doi: 10.1016/j.jaut.2009.11.006.

Romeo, T., Pietro, B., Peda, C., Consoli, P., Andaloro, F. and Fossi, M. C. 2015. First evidence of presence of plastic debris in stomach of large pelagic fish in the Mediterranean Sea. Mar. Pollut. Bull., 95: 358-361. doi: 10.1016/j. marpolbul.2015.04.048.

Rieux, A. D., Ragnarsson, E. G. E., Gullberg, E., Preeat, V., Schneider, Y. J. and Artursson, P. 2005. Transport of nanoparticles across an in vitro model of the human intestinal follicle associated epithelium. Eur. J. Pharm. Sci., 25: 455-465. DOI: 10.1016/j.ejps.2005.04.015.

Sajikumar, K. K., Ragesh, N., Remya, R. and Mohamed, K. S. 2013. Occurrence of plastic debris in the stomach of 
yelowfin tuna (Thunnus albacares) from the Arabian sea: A cause of concern. Mar. Fish. Infor. Serv. T\& E Ser., 217: p. 13.

SAPEA 2019. A scientific perspective on microplastics in nature and society. Science Advice for Policy by European Academies, SAPEA, Berlin. https://doi.org/10.26356/ microplastics.

Sanchez, W., Bender, C. and Porcher, J. M. 2014. Wild gudgeons (Gobiogobio) from French rivers are contaminated by microplastics: Preliminary study and first evidence. Environ. Res., 128: 98-100.doi: 10.1016/j.envres.2013.11. 004.

Sass, W., Dreyer, H. P. and Seifert, J. 1990. Rapid insorption of small particles in the gut. Am. J. Gastroenterol., 85: 255-260.

Sharma, S. and Chatterjee, S. 2017. Microplastic pollution, a threat to marine ecosystem and human health: a short review. Environ. Sci. Pollut. Res., 24: 21530-21547. doi: 10.1007/s11356-017-9910-8.

Shylaja, G., Kripa, V., Prema, D. and Abhilash, K. S. 2018. Assessment of marine debris in the stake net fisheries of Vembanad Lake, Kerala, India. J. Mar. Biol. Ass. India, 60: 91-96. doi: 10.6024/jmbai.2018.60.1.2044-14.

Silvestre, C., Duraccio, D. and Cimmino, S. 2011. Food packaging based on polymer nanomaterials. Prog. Polym. Sci., 36: 1766-1782. DOI: 10.1016/j.progpolymsci.2011.02.003.

Sruthy, S. and Ramasamy, E. V. 2017. Microplastic pollution in Vembanad Lake, Kerala, India: The first report of microplastics in lake and estuarine sediments in India. Environ. Pollut., 222: 315-322. doi: 10.1016/j.envpol. 2016.12.038.

Stasolla, G., Innocenti, G. and Galil, B. S. 2015. On the diet of the invasive crab Charybdis longicollis Leene, 1938 (Brachyura: Portunidae) in the eastern Mediterranean Sea. Isr. J. Ecol. Evol., 61: 130-134. doi.org/10.1080/15659801. 2015.1123362.

Stone, N. J. 1996. Fish consumption, fish oil, lipids and coronary heart disease. Circulation, 94: 2337-2340.

Sulochanan, Bindu, Bhat, G. S. and Lavanya, S. 2011. Marine litter in the coastal environment of Mangalore. Mar. Fish. Infor. Serv. T\& E Ser., 208: 18-19.

Sussarellu, R., Suquet, M., Thomas, Y., Lambert, C., Fabioux, C., Pernet, M. E. J., Goic, N. L., Quillien, V., Mingant, C., Epelboin, Y., Corporeau, C., Guyomarch, J., Robbens, J., Paul-Pont, I., Soudant, P. and Huvet, A. 2016. Oyster reproduction is affected by exposure to polystyrene microplastics. PNAS, 113: 2430-2435.doi.org/10.1073/ pnas. 1519019113.

Thompson, R. C. 2006. Plastic debris in the marine environment: Consequences and solutions. In: Krause, J. C., Nordheim, H., Brager, S. (Eds.), Marine nature conservation in Europe.
Stralsund (DE): Federal Agency for Nature Conservation, p. 107-115.

UNEP 2014. Plastic waste causes financial damage of US\$13 billion to marine ecosystems each year as concern grows over microplastics. United Nations Environment Programme. https://www.unenvironment.org/news-andstories/press-release/plastic-waste-causes-financialdamage-us13-billion-marine-ecosystems.

Van Cauwenberghe, L. and Janssen, C. 2014. Microplastics in bivalves cultured for human consumption. Environ Pollut., 193: 65-70. doi.org/10.1016/j.envpol.2014.06.010.

Van Cauwenberghe, L., Claessens, M., Vandegehuchte, M. B., Janssen, C. R. 2015. Microplastics are taken up by mussels (Mytilus edulis) and lugworms (Arenicola marina) living in natural habitats. Environ Pollut., 199: 10-17. doi: 10.10 16/j.envpol.2015.01.008.

Veerasingam, S., Saha, M., Suneel, V., Vethamony, P., Rodrigues, C. A., Bhattacharyya, S. and Naik, B. G. 2016. Characteristics, seasonal distribution and surface degradation features of microplastic pellets along the Goa coast, India, Chemosphere, 159: 496-505.doi: 10.1016/j. chemosphere.2016.06.056.

Vethaak, A. D. and Leslie, H. A. 2016. Plastic debris is a human health issue. Environ. Sci. Technol., 50: 6825-6826. http:// dx.doi.org/10.1021/acs.est.6b02569.

Volkheimer, G. 1975. Hematogenous dissemination of ingested polyvinyl chloride particles. Ann. N. Y. Acad. Sci., 246: 164-171. DOI: 10.1111/j.1749-6632.1975.tb51092.x.

Wieczorek, A. M., Morrison, L., Croot, P. L., Allcock, A. L., MacLoughlin, E., Savard, O., Brownlow, H. and Doyle, T. K. 2018. Frequency of microplastics in mesopelagic fishes from the North-west Atlantic. Front. Mar. Sci., 5: 39 pp. doi: 10.3389/fmars.2018.00039.

Woodall, L.C., Sanchez-Vidal, A., Canals, M., Paterson, G.L.J., Coppock, R., Sleight, V., Calafat, A., Rogers, A. D., Narayanaswamy, B. E. and Thompson, R.C. 2014. The deep sea is a major sink for microplastic debris. $R$. Soc. Open Sci., 1: 140317.

Wright, S. L. and Kelly, F. 2017. Plastic and human health: a micro issue? Environ. Sci. Technol., 51:6634-6647. DOI: $10.1021 /$ acs.est.7b00423.

Xiong, X., Zhang, K., Chen, X., Shi, H., Luo, Z. and Wu, C. 2018. Sources and distribution of microplastics in China's largest inland lake - Qinghai Lake. Environ. Pollut., 235: 899-906.

Yang, C. Z., Yaniger, S. I., Jordan, V. C., Klein, D. J. and Bittner, G. D. 2011. Most plastic products release estrogenic chemicals: a potential health problem that can be solved. Environ. Health Perspect., 119: 989-996.

Yang, D., Shi, H., Li, L., Li, J., Jabeen, K. and Kolandhasamy, P. 2015. Microplastic pollution in table salts from China. 
Environ. Sci. Technol., 49: 13622-13627. doi: 10.1021/acs. est.5b03163.

Yonkos, L.T., Friedel, E. A., Perez-Reyes, A. C., Ghosal, S. and Arthur, C. D. 2014. Microplastics in four estuarine rivers in the Chesapeake Bay, U.S.A. Environ. Sci. Technol., 48: 14195-14202.DOI: 10.1021/es5036317.
Yu, X., Peng, J., Wang, J., Wang, K. and Bao, S. 2018. Occurrence of microplastics in the beach sand of the Chinese inner sea: the Bohai Sea. Environ. Pollut., 214: 722-730.

Zhang, W., Ma, X., Zhang, Z., Wang, Y., Wang, J., Wang, J. and Ma, D. 2015. Persistent organic pollutants carried on plastic resin pellets from two beaches in China. Mar. Pollut. Bull., 99: 28-34. doi: 10.1016/j.marpolbul.2015.08.002. 